\title{
Antifungal susceptibility profile of Aspergillus fumigatus isolates from avian lungs ${ }^{1}$
}

\author{
Andréia Spanamberg ${ }^{2,3 *}$ (D), Ana Paula Ravazzolo ${ }^{4}$, Laura B. Denardi ${ }^{5}$, \\ Sydney A. Hartz ${ }^{5}$, Janio M. Santurio ${ }^{5}$, David Driemeier ${ }^{6}$ and Laerte Ferreiro ${ }^{2,3}$
}

\begin{abstract}
Spanamberg A., Ravazzolo A.P., Denardi L.B., Hartz S.A., Santurio J.M., Driemeier D. \& Ferreiro L. 2020. Antifungal susceptibility profile of Aspergillus fumigatus isolates from avian lungs. Pesquisa Veterinária Brasileira 40(2):102-106. Setor de Micologia, Faculdade de Veterinária, Universidade Federal do Rio Grande do Sul, Av. Bento Gonçalves 9090, Porto Alegre, RS 91540-000, Brazil. E-mail: spanamberg.ad@gmail.com

Susceptibility testing is essential to inform the correct management of Aspergillus infections. In this study we present antifungal susceptibility profile of $A$. fumigatus isolates recovered from lungs of birds with and without aspergillosis. Fifty three isolates were tested for their antifungal susceptibility to voriconazole (VRC), itraconazole (ITZ), amphotericin (AMB) and caspofungin (CSP) using the M38-A2 broth microdilution reference method. Five isolates were resistant to more than one antifungal drug (CSP + AMB, VRC + ITZ and AMB + ITZ). Fifteen (28\%) isolates with susceptible increased exposure (I) to ITZ were sensible to VRC. Resistance to AMB ( $>2 \mu \mathrm{g} / \mathrm{mL}$ ) was observed in only four isolates. Eleven $(21 \%)$ A. fumigatus present resistance to ITZ (13\%) and VRC (8\%). Fungal isolation from respiratory samples has been regarded as being of limited usefulness in the ante mortem diagnosis of aspergillosis in birds. However, the results suggest that the detection and antifungal susceptibility profile may be helpful for monitoring of therapy for avian species and where antifungal resistance might be emerging and what conditions are associated to the event.
\end{abstract}

INDEX TERMS: Aspergillus fumigatus, antifungal, susceptibility, isolates, birds, lungs.

RESUMO.- [Perfil de suscetibilidade antifúngica de isolados de Aspergillus fumigatus provenientes de pulmões de aves.] Os testes de suscetibilidade são essenciais para informar o correto manejo das infecções por Aspergillus. Neste estudo apresentamos o perfil antifúngico de isolados de $A$. fumigatus provenientes de pulmões de aves com e sem aspergilose. Cinqüenta e três isolados foram testados

\footnotetext{
${ }^{1}$ Received on June 12, 2019.

Accepted for publication on September 5, 2019.

${ }^{2}$ Setor de Micologia, Faculdade de Veterinária (FaVet), Universidade Federal do Rio Grande do Sul (UFRGS), Av. Bento Gonçalves 9090, Bairro Agronomia, Porto Alegre, RS 91540-000, Brazil. *Corresponding author: spanamberg.ad@gmail.com

${ }^{3}$ Graduate Program in Veterinary Science, Universidade Federal do Rio Grande do Sul (UFRGS), Av. Bento Gonçalves 9090, Bairro Agronomia, Porto Alegre, RS 91540-000.

${ }^{4}$ Laboratório de Imunologia e Biologia Molecular, Faculdade de Veterinária (FaVet), Universidade Federal do Rio Grande do Sul (UFRGS), Av. Bento Gonçalves 9090, Bairro Agronomia, Porto Alegre, RS 91540-000.

${ }^{5}$ Laboratório de Pesquisas Micológicas (Lapemi), Departamento de Microbiologia, Universidade Federal de Santa Maria (UFSM), Campus UFSM, prédio 20, Santa Maria, RS 97105-900, Brazil.

${ }^{6}$ Setor de Patologia Veterinária, Faculdade de Veterinária (FaVet), Universidade Federal do Rio Grande do Sul (UFRGS), Av. Bento Gonçalves 9090, Bairro Agronomia, Porto Alegre, RS 91540-000.
}

quanto à susceptibilidade antifúngica ao voriconazol (VRC), itraconazol (ITZ), anfotericina B (AMB) e caspofungina (CSP) pelo método de referência de microdiluição do caldo M38-A2. Cinco isolados foram resistentes a mais de um antifúngico (CSP + AMB, VRC + ITZ e AMB + ITZ). Quinze (28\%) isolados suscetíveis - com exposição aumentada (I) ao ITZ foram sensíveis ao VRC. A resistência ao AMB ( $>2 \mu \mathrm{g} / \mathrm{mL})$ foi observada em apenas quatro isolados. Onze (21\%) A. fumigatus apresentaram resistência a ITZ (13\%) e VRC (8\%). 0 isolamento de fungos de amostras respiratórias tem sido considerado de utilidade limitada no diagnóstico ante mortem de aspergilose em aves. No entanto, os resultados sugerem que a detecção e o perfil de suscetibilidade a antifúngicos podem ser úteis para o monitoramento da terapia de espécies aviárias, assim como a emergência da resistência antifúngica e quais condições podem estar associadas ao evento.

TERMOS DE INDEXAÇÃO: Aspergillus fumigatus, antifúngicos, suscetibilidade, isolados, aves, pulmões.

\section{INTRODUCTION}

Aspergillosis is a fungal infection that causes high economic losses in poultry production. Aspergillus belonging to section Fumigati is the main causative agent of aspergillosis in birds, 
it is commonly found in bed, soil and decomposing organic matter or in feed. Birds become infected through aspiration in large numbers of conidia (Dagenais \& Keller 2009, Serrano et al. 2011). Aspergillus fumigatus may be present in the lungs of healthy birds and/or may be causing bird's diseases. The avian respiratory tract is the most affected, because small conidia easily reaches to the lungs and air sacs of the birds and from the lungs can produce a systemic infection (Fedde 1998, Beernaert et al. 2009).

Three antifungal classes are available for the treatment of aspergillosis, polyenes, azoles and echinocandins. Azoles inhibit the synthesis of ergosterol causing damage to the fungal cell membrane and currently, are the first line of treatment of Aspergillus infections with voriconazole (VRC) the choice treatment for invasive aspergillosis in humans (Walsh et al. 2008 ). At the same time, a large number of $A$. fumigatus isolates resistant to azoles recovered from environmental and patients have been reported in many countries of the world (Diaz-Guerra et al. 2003, Mellado et al. 2004, Snelders et al. 2009). Although not much reported yet, resistance to azoles has already been documented in Aspergillus infections in birds (Beernaert et al. 2009).

Echinocandins (caspofungin, micafungin, and anidulafungin) are the most recent class of antifungal agents that have action against Aspergillus, they act by inhibiting the synthesis of glucans, essential components for the fungal cell wall. Only caspofungin (CSP) is licensed for the treatment of aspergillosis, while micafungin and anidulafungin, although good in vitro action, still require dose adjustments in vivo. Echinocandin resistance is still considered as unusual (Walsh et al. 2008, Pfaller et al. 2009), although some studies show variable susceptibility to caspofungin were observed in vitro against $A$. fumigatus species complex (Barrs et al. 2013, Pelaez et al. 2013). Also, other authors have reported differences of Aspergillus spp. susceptibility to echinocandins (Denardi et al. 2018).

Amphotericin B (AMB) has been used for more than 40 years in aspergillosis treatment and also targets the fungal cell membrane. Its less toxic lipid formulations have been used in cases of aspergillosis refractory to azole antifungals (Linden 2003). Resistance to AMB is a rare phenomenon in A. fumigatus, however $A$. terreus is intrinsically resistant and $A$. flavus has reduced sensitivity to this antifungal (Gonçalves et al. 2016).

Susceptibility testing is essential to inform the correct management of Aspergillus infections in humans and animals. In this study we present antifungal susceptibility profile of A. fumigatus isolates recovered from lungs of birds with and without aspergillosis.

\section{MATERIALS AND METHODS}

Aspergillus isolates and molecular identification. A total of 53 A. fumigatus isolates from lungs of health broilers $(n=34)$ and with aspergillosis $(n=19)$ were included in the study. The isolates were recovered from lung samples from 2010 to 2016 after post-mortem examination of birds. They were deposited in the culture collection of the "Laboratório de Pesquisas Micológicas", "Faculdade de Veterinária" (FaVet), "Universidade Federal do Rio Grande do Sul” (UFRGS), and maintained by periodic sub-culture. The study (Project no. 26640) was approved by the Research Committee of Faculty of VeterinaryUFRGS. All isolates were identified as A. fumigatus by macro and micromorphology and molecular methods. The Qiagen DNeasy ${ }^{\circledR}$ plant mini DNA extraction kit (Qiagen, Hilden, Germany) protocol was used to extract DNA from the Aspergillus conidia according to manufacturer instructions. Molecular identification was performed using specific primers for identification of Aspergillus section Fumigati and A. fumigatus (Spanamberg et al. 2016). Multiplex PCR amplification was performed a total volume of $25 \mu \mathrm{L}$ containing $1 \mu \mathrm{L}$ of DNA extract, 12.5 $\mu \mathrm{L}$ Qiagen Taq PCR master mix (Qiagen, Hilden, Germany) and $0.5 \mu \mathrm{L}$ of each primer (for a $0.2 \mu \mathrm{M}$ final concentration of each primer). The cycling parameters was as follow: pre-incubation at $94^{\circ} \mathrm{C}$ for $15 \mathrm{~min}, 35$ cycles of denaturation at $94^{\circ} \mathrm{C}$ for $30 \mathrm{~s}$, annealing at $69^{\circ} \mathrm{C}$ for $90 \mathrm{~s}$, extension at $72^{\circ} \mathrm{C}$ for $1 \mathrm{~min}$, and a final extension step of $10 \mathrm{~min}$ at $72^{\circ} \mathrm{C}$. Samples were analyzed by electrophoresis through $2 \%$ agarose gels. Gels were stained with ethidium bromide and DNA was visualized under UV. The electrophoretic profile with three bands (105, 198 and 313bp) was similar in all tested strains of $A$. fumigatus. The reference $A$. fumigatus strain ATCC 46645 was identified according to standard conditions yielding a final electrophoretic profile corresponding to A. fumigatus (Serrano et al. 2011). PCR product was purified using PuriLink ${ }^{\mathrm{TM}}$ PCR Purification Kit (Invitrogen), and sequencing to confirm the identity.

Drug susceptibility assays in A. fumigatus. Isolates were tested for their antifungal susceptibility to ITZ, VRC, AMB and CSP using the M38-A2 broth microdilution reference method (CLSI 2008). All antifungal drugs were obtained as standard powders. ITZ and AMB were obtained from Sigma-Aldrich (São Paulo/SP, Brazil) and CSP (Merck Sharp and Dohme, São Paulo/SP, Brazil) and VCZ (Laboratórios Pfizer Ltda, São Paulo/SP, Brazil) from their respective manufacturers. Stock solutions of all antifungal drugs were prepared in dimethyl sulfoxide (DMSO) and storage at $-70^{\circ} \mathrm{C}$. The final antifungal concentrations tested ranged from 0.031 to $16 \mu \mathrm{g} / \mathrm{mL}$ for azoles and AMB, and from 0.001 to $0.500 \mu \mathrm{g} / \mathrm{mL}$ for CAS.

The inoculum was prepared from cultures grown for $48-72 \mathrm{~h}$ at $37^{\circ} \mathrm{C}$ in Potato Dextrose Agar (PDA). Saline solution ( $2 \mathrm{~mL}$ ) with $0.1 \%$ Tween 20 was added to tubes counting the A. fumigatus colonies and the conidia were carefully collected with a sterile loop. The suspensions remained standing for 2 to $5 \mathrm{~min}$ for sedimentation of the hyphae, after the conidial suspension was transferred to another sterile tube. Then, the suspensions were adjusted in spectrophotometer at $\Lambda=530 \mathrm{~nm}$ and absorbance of 0.09 to 0.13 . To obtain a final working inoculum concentration of 0.4 to $5 \times 10^{4}$ cells $/ \mathrm{mL}$, a 1:50 dilution was made in RPMI. A total of $100 \mu \mathrm{L}$ of the inoculum was placed into the microdilution wells containing the different concentrations of each antifungal drug. The plates were incubated at $35^{\circ} \mathrm{C}$. The MEC (minimal effective concentration, resulting in abnormal, short, and branched hyphae) readings were taken after $24 \mathrm{~h}$ to CAS and the MIC (minimal inhibitory concentration, $100 \%$ of inhibition) readings at 48h for azoles and AMB. A. fumigatus was classified as susceptible - standard doing regimen (S), susceptible - increased exposure (I) and resistant $(\mathrm{R})$ following the breakpoints proposed by EUCAST table v. 9.0 and Arendrup et al. (2019): ITZ and VRC $\leq 1 \mu \mathrm{g} / \mathrm{mL}(\mathrm{S})$, $2 \mu \mathrm{g} / \mathrm{mL}(\mathrm{I})$ and $>2 \mu \mathrm{g} / \mathrm{mL}(\mathrm{R}) ; \mathrm{AMB} \leq 1 \mu \mathrm{g} / \mathrm{mL}(\mathrm{S})$ and $>2 \mu \mathrm{g} / \mathrm{mL}(\mathrm{R})$; and $\mathrm{CSP} \geq 0.5 \mu \mathrm{g} / \mathrm{mL}(\mathrm{R})$.

\section{RESULTS}

All isolates were confirmed as Aspergillus fumigatus stricto sensu following the amplification of $\beta$-tub and $\operatorname{rodA}$ gene fragments and gel electrophoresis. The results of in vitro susceptibilities tests are show in Table 1, Figure 1 and Figure 2. Five isolates were resistant to more than one antifungal drug (CSP + AMB, VRC + ITZ and AMB + ITZ). Fifteen (28\%) isolates with susceptible increased exposure to ITZ were sensible to VRC. Resistance to AMB ( $>2 \mu \mathrm{g} / \mathrm{mL})$ was observed in only four isolates. 
Table 1. Antifungal susceptibility profile of Aspergillus fumigatus isolates from avian lungs

\begin{tabular}{|c|c|c|c|c|}
\hline \multirow{2}{*}{ A. fumigatus isolates } & \multirow{2}{*}{ Antifungal } & MIC Range $^{\mathrm{a}}$ & $\mathrm{MIC}_{50}{ }^{\mathrm{b}}$ & $\mathrm{MIC}_{90}{ }^{\mathrm{c}}$ \\
\hline & & \multicolumn{3}{|c|}{$\mu \mathrm{g} / \mathrm{mL}$} \\
\hline \multirow{4}{*}{$\begin{array}{l}\text { Aspergillosis cases } \\
n=19(36 \%)\end{array}$} & Itraconazole & $0.5-32.0$ & 1.0 & 2.0 \\
\hline & Voriconazole & $0.5-8.0$ & 0.5 & 0.5 \\
\hline & Amphotericin & $0.5-4.0$ & 1.0 & 2.0 \\
\hline & Caspofungin & $0.003-0.125$ & 0.06 & 0.125 \\
\hline \multirow{4}{*}{$\begin{array}{l}\text { Aspergillus lung colonization } \\
\mathrm{n}=34(64 \%)\end{array}$} & Itraconazole & $0.5-32.0$ & 1.0 & 16.0 \\
\hline & Voriconazole & $0.5-32.0$ & 0.5 & 0.5 \\
\hline & Amphotericin & $0.5-8.0$ & 1.0 & 2.0 \\
\hline & Caspofungin & $0.03-0.5$ & 0.06 & 0.125 \\
\hline
\end{tabular}

${ }^{a}$ Variation of MIC values (number of dilution variation) for every antifungal, ${ }^{\mathrm{b}}$ minimal inhibitory concentration required for inhibit the growth of $50 \%$ of the strains, ${ }^{\mathrm{c}}$ minimal inhibitory concentration required for inhibit the growth of $90 \%$ of the strains

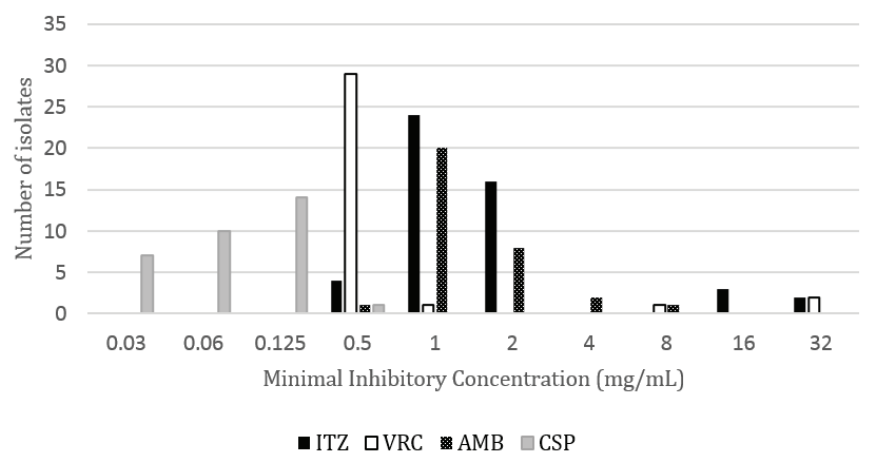

Fig.1. Antifungal susceptibility profile of Aspergillus fumigatus isolates $(\mathrm{n}=34)$ from avian lungs with fungal colonization. Itraconazole (ITZ), voriconazole (VCR), amphotericin B (AMB), caspofungin (CSP). A. fumigatus was classified as susceptible - standard doing regimen (S), susceptible-increased exposure (I) and resistant (R) following the breakpoints: ITZ and VRC $\leq 1 \mu \mathrm{g} / \mathrm{mL}(\mathrm{S})$, $2 \mu \mathrm{g} / \mathrm{mL}(\mathrm{I})$ and $>2 \mu \mathrm{g} / \mathrm{mL}(\mathrm{R}) ; \mathrm{AMB} \leq 1 \mu \mathrm{g} / \mathrm{mL}(\mathrm{S})$ and $>2 \mu \mathrm{g} / \mathrm{mL}(\mathrm{R})$; and $\mathrm{CSP} \geq 0.5 \mu \mathrm{g} / \mathrm{mL}(\mathrm{R})$.

\section{DISCUSSION}

Aspergillus is found worldwide causing infections in humans and animals and is considered as one of the major respiratory pathogens in birds (Arné et al. 2011), being frequently reported in the recent Brazilian veterinary literature (Spanamberg et al. 2012, Silva Filho et al. 2015, Echenique et al. 2016). All isolates in this study were $A$. fumigatus obtained from healthy birds and ones with aspergillosis (without previous antifungal therapy). Similar results were observed by other authors who demonstrated the dominant association of Aspergillus fumigatus stricto sensu in avian mycoses (Sabino et al. 2019). Papers about antifungal susceptibility of $A$. fumigatus from avian lung samples are scarce. Molecular identification is very important to understand the evolution of resistance pattern of $A$. fumigatus stricto sensu, because the species of section Fumigati may present distinct susceptibility profiles (Snelders et al. 2009). In addition, the significant increase in the use of antifungal agents, both for human treatment and use of azole fungicides in agricultural crop protection has influenced the emergence of resistant clinical isolates,

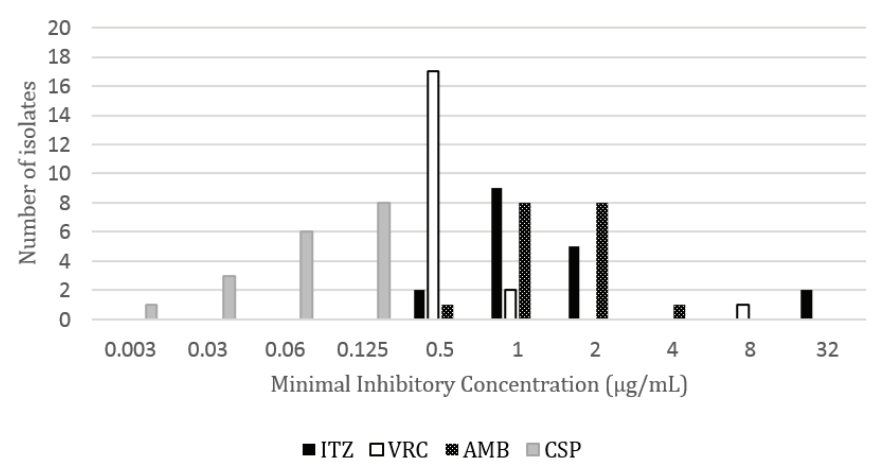

Fig.2. Antifungal susceptibility profile of Aspergillus fumigatus isolates $(n=19)$ from avian lungs with aspergillosis. Itraconazole (ITZ), voriconazole (VCR), amphotericin B (AMB), caspofungin (CSP). A. fumigatus was classified as susceptible - standard doing regimen (S), susceptible-increased exposure (I) and resistant (R) following the breakpoints: ITZ and VRC $\leq 1 \mu \mathrm{g} / \mathrm{mL}$ (S), $2 \mu \mathrm{g} / \mathrm{mL}(\mathrm{I})$ and $>2 \mu \mathrm{g} / \mathrm{mL}(\mathrm{R}) ; \mathrm{AMB} \leq 1 \mu \mathrm{g} / \mathrm{mL}(\mathrm{S})$ and $>2 \mu \mathrm{g} / \mathrm{mL}(\mathrm{R}) ;$ and $\mathrm{CSP} \geq 0.5 \mu \mathrm{g} / \mathrm{mL}(\mathrm{R})$.

particularly to the triazoles and echinocandins (Gonçalves 2017).

Resistance to AMB (MIC $>2 \mu \mathrm{g} / \mathrm{mL}$ ) was observed in four $(7 \%)$ isolates. This finding is in disagreement with results reported in the literature. In a study conducted by Silvanose et al. (2006), for 16 A. fumigatus, 5 (31\%) isolates showed resistance (MIC of AMB $>2.0 \mu \mathrm{g} / \mathrm{mL}$ ). Ziołkowska et al. (2014) also showed resistance for $60(70.6 \%)$ A. fumigatus isolates (MIC range of AMB for 4 to $16 \mu \mathrm{g} / \mathrm{mL}$ ). The low degree of resistance to amphotericin B found in the study can be explained by the lack of use of this drug as prophylactic measure in poultry farming. In relationship to isolates obtained from humans, A. fumigatus is rarely resistant to this antifungal unlike Aspergillus nidulans and Aspergillus terreus (Newton et al. 2016). In domestic as well as in captive birds (non-poultry species), several management strategies against aspergillosis have been suggested, and the nebulization with AMB is used in breeding establishments to prophylactically (Orosz 2000, Rochette et al. 2003).

Our isolates showed most overall resistance to ITZ. Eleven (21\%) A. fumigatus present resistance to ITZ (13\%) and VRC (8\%), being five isolates above MIC $>16 \mu \mathrm{g} / \mathrm{mL}$ for both 
antifungals. Azole resistance might be developed through the use of azole compounds in the environment and specifically in the case of birds; conditions that favor the development of fungi in confinement buildings expose commercial poultry to a higher risk of inhaling conidia of $A$. fumigatus during the farming period. Under these conditions, birds could inhale resistant conidia and subsequently develop azole-resistant disease or have fungal colonization in respiratory tract (Arné et al. 2011, Spanamberg et al. 2013). The use of fungistatic agents (sprayed, fogged, or nebulized to treat surfaces or indoor) like thiabendazole, nystatin, or copper sulfate contributes to decreased fungal contamination of beddings. Enilconazole is available in special formulations for decontamination of the poultry houses (Seyedmousavi et al. 2015).

Aspergillus species are present in a wide variety of substrates and environments as saprophytic, prevalently found in soil, decaying vegetation and compost. Furthermore, azoles are commonly used for plant protection as well as material preservation. The present study detected two azole-resistant A. fumigatus isolated from birds without aspergillosis, suggesting that resistance might be developed in the environmental conditions, which can favors the appearance of strains cross-resistant to medical triazoles used for treatment of human aspergillosis (Serfling et al. 2007).

\section{CONCLUSION}

Fungal isolation from respiratory samples has been regarded as being of limited usefulness in the ante mortem diagnosis of aspergillosis in birds. However, the results suggest that the identification and antifungal susceptibility profile may be helpful for monitoring of therapy for avian species and where antifungal resistance might be emerging and what conditions are associated to the event.

Acknowledgements.- Financial support was received from "Coordenação de Aperfeiçoamento de Pessoal de Nível Superior" (CAPES-PNPD) and “Conselho Nacional de Pesquisa” (CNPq): grant \#306685/2015-9 (PQ 1D). Thanks are extended to Veterinary Pathology Sector of FAVET-UFRGS and PhD Ricardo Araujo (IPATIMUP).

Conflict of interest statement.- The authors report no conflicts of interest. The authors are responsible for the content and writing of the paper.

\section{REFERENCES}

Arendrup M.C., Guinea J. \& Cuenca-Estrella M. 2019. EUCAST Technical Note on the method for the determination of broth dilution minimum inhibitory concentrations of antifungal agents for conidia-forming moulds. Clin. Microbiol. Infect. 14(10):982-984. <PMid:18828858>

Arné P., Thierry S., Wang D., Deville M., Le Loc'h G., Desoutter A., Féménia F., Nieguitsila A., Huang W., Chermette R. \& Guillot J. 2011. Aspergillus fumigatus in poultry. Int. J. Microbiol. 2011:746356. <http://dx.doi. org/10.1155/2011/746356><PMid:21826144>

Barrs V.R., Van Doorn T.M., Houbraken J., Kidd S.E., Martin P., Pinheiro P.D., Richardson M., Varga J. \& Samson R.A. 2013. Aspergillus felis sp. nov., an emerging agent of invasive aspergillosis in humans, cats, and dogs. PLoS One 8(6):e64871. <http://dx.doi.org/10.1371/journal.pone.0064871> $<$ PMid:23798996>

Beernaert L.A., Pasmans F., Van Waeyenberghe L., Dorrestein G.M., Verstappen F., Vercammen F., Haesebrouck F. \& Martel A. 2009. Avian Aspergillus fumigatus strains resistant to both itraconazole and voriconazole. Antimicrob. Agents
Chemother. 53(5):2199-2201. <http://dx.doi.org/10.1128/AAC.0149208> <PMid:19258265>

CLSI 2008. M38-A2: Reference method for broth dilution antifungal susceptibility testing of filamentous fungi: approved standard. 2 nd ed. Clinical and Laboratory Standards Institute, Wayne, Pennsylvania. 35p.

Dagenais T.R.T. \& Keller N.P. 2009. Pathogenesis of Aspergillus fumigatus in invasive aspergillosis. Clin. Microbiol. Rev. 22(3):447-465. <http://dx.doi. org/10.1128/CMR.00055-08> <PMid:19597008>

Denardi L.B., Dalla-Lana B.H., Jesus F.P.K., Severo C.B., Santurio J.M., Zanette R.A. \& Alves S.H. 2018. In vitro antifungal susceptibility of clinical and environmental isolates of Aspergillus fumigatus and Aspergillus flavus in Brazil. Braz. J. Infect. Dis. 22(1):30-36. <http://dx.doi.org/10.1016/j. bjid.2017.10.005><PMid:29172033>

Diaz-Guerra T.M., Mellado E., Cuenca-Estrella M. \& Rodriguez-Tudela J.L. 2003. A point mutation in the 14 alpha-sterol demethylase gene cyp $51 \mathrm{~A}$ contributes to itraconazole resistance in Aspergillus fumigatus. Antimicrob. Agents Chemother. 47(3):1120-1124. <http://dx.doi.org/10.1128/ AAC.47.3.1120-1124.2003><PMid:12604551>

Echenique J.V.Z., Bandarra P.M., Brauner R.K., Soares M.P., Coimbra M.A.A. \& Schild A.L. 2016. Infecção por poxvírus e Aspergillus fumigatus em Bubo virginianus (coruja jacurutu). Pesq. Vet. Bras. 36(7):630-633. <http:// dx.doi.org/10.1590/S0100-736X2016000700012>

Fedde M.R. 1998. Relationship of structure and function of the avian respiratory system to disease susceptibility. Poult. Sci. 77(8):1130-1138. <http:// dx.doi.org/10.1093/ps/77.8.1130><PMid:9706077>

Gonçalves S.S. 2017. Global aspects of triazole resistance in Aspergillus fumigatus with focus on Latin American countries. J. Fungi, Basel 3(1):5. <http://dx.doi.org/10.3390/jof3010005><PMid:29371524>

Gonçalves S.S., Souza A.C.R., Chowdhary A., Meis J.F. \& Colombo A.L. 2016. Epidemiology and molecular mechanisms of antifungal resistance in Candida and Aspergillus. Mycoses 59(4):198-219. <http://dx.doi.org/10.1111/ myc.12469><PMid:26810669>

Linden P.K. 2003. Amphotericin B lipid complex for treatment of invasive fungal infections. Expert Opin. Pharmacother. 4(11):2099-2110.<http:// dx.doi.org/10.1517/14656566.4.11.2099><PMid:14596663>

Mellado E., Garcia-Effron G., Alcazar-Fuoli L., Cuenca-Estrella M. \& RodriguezTudela J.L. 2004. Substitutions at methionine 220 in the 14 alpha-sterol demethylase (Cyp51A) of Aspergillus fumigatus are responsible for resistance in vitro to azole antifungal drugs. Antimicrob. Agents Chemother. 48(7):2747-2750. <http://dx.doi.org/10.1128/AAC.48.7.2747-2750.2004> $<$ PMid:15215142>

Newton P.J., Harris C., Morris J. \& Denning D.W. 2016. Impact of liposomal amphotericin B therapy on chronic pulmonary aspergillosis. J. Infect. 73(5):485495. <http://dx.doi.org/10.1016/j.jinf.2016.06.001><PMid:27373381>

Orosz S.E. 2000. Overview of aspergillosis: pathogenesis and treatment options. J. Exot. Pet Med. 9:59-65.

Peláez T., Alvarez-Perez S., Mellado E., Serrano D., Valerio M., Blanco J.L., Garcia M.E., Munoz P., Cuenca-Estrella M. \& Bouza E. 2013. Invasive aspergillosis caused by cryptic Aspergillus species: a report of two consecutive episodes in a patient with leukaemia. J. Med. Microbiol. 62(Pt 3):474-478. <http:// dx.doi.org/10.1099/jmm.0.044867-0><PMid:23161769>

Pfaller M.A., Boyken L., Hollis R.J., Kroeger J., Messer S.A., Tendolkar S. \& Diekema D.J. 2009. In vitro susceptibility of clinical isolates of Aspergillus spp. to anidulafungin, caspofungin, and micafungin: a head-to-head comparison using the CLSI M38-A2 broth microdilution method. J. Clin. Microbiol. 47(10):3323-3325. <http://dx.doi.org/10.1128/JCM.0115509><PMid:19710267>

Rochette F., Engelen M. \& Vanden Bossche H. 2003. Antifungal agents of use in animal health- practical applications. J. Vet. Pharmacol. Ther. 26(1):31-53. <http://dx.doi.org/10.1046/j.1365-2885.2003.00457.x><PMid:12603775> 
Sabino R., Burco J., Valente J., Veríssimo C., Clemons K.V., Stevens D.A. \& Tell L.A. 2019. Molecular identification of clinical and environmental avian Aspergillus isolates. Arch. Microbiol. 201(2):253-257. <http://dx.doi. org/10.1007/s00203-019-01618-y ><PMid:30627760>

Serfling A., Wohlrab J. \& Deising H.B. 2007. Treatment of a clinically relevant plant-pathogenic fungus with an agricultural azole causes crossresistance to medical azoles and potentiates caspofungin efficacy. Antimicrob. Agents Chemother. 51(10):3672-3676.<http://dx.doi.org/10.1128/AAC.0065407> <PMid:17620378>

Serrano R., Gusmão L., Amorim A. \& Araujo R. 2011. Rapid identification of Aspergillus fumigatus within the section Fumigati. BMC Microbiol. 11(1):82. <http://dx.doi.org/10.1186/1471-2180-11-82> <PMid:21510879>

Seyedmousavi S., Guillot J., Arné P., de Hoog G.S., Mouton J.W., Melchers W.J. \& Verweij P.E. 2015. Aspergillus and aspergilloses in wild and domestic animals: a global health concern with parallels to human disease. Med. Mycol. 53(8):765-797. <http://dx.doi.org/10.1093/mmy/myv067> <PMid:26316211>

Silva Filho R.P., Xavier M.O., Martins A.M., Ruoppolo V., Mendoza-Sassi R.A., Adornes A.C., Cabana A.L. \& Meireles M.C. 2015. Incidence density, proportionate mortality, and risk factors of aspergillosis in magellanic penguins in a rehabilitationcenter from Brazil. J. Zoo Wildl. Med. 46(4):667674. <http://dx.doi.org/10.1638/2013-0092.1> <PMid:26667521>

Silvanose C.D., Bailey T.A. \& Di Somma A. 2006. Susceptibility of fungi isolated from the respiratory tract of falcons to amphotericin B, itraconazole and voriconazole. Vet. Rec. 159(9):282-284. <http://dx.doi.org/10.1136/ vr.159.9.282><PMid:16946311>
Snelders E., Huis In 't Veld R.A., Rijs A.J., Kema G.H., Melchers W.J. \& Verweij P.E. 2009. Possible environmental origin of resistance of Aspergillus fumigatus to medical triazoles. Appl. Environ. Microbiol. 75(12):4053-4057. <http:// dx.doi.org/10.1128/AEM.00231-09><PMid:19376899>

Spanamberg A., Casagrande R.A., Ferreiro L., Rolim V.M., Souza S.O., Gonçalves I.C.M., Oliveira L.G.S., Wouters F., Wouters A.T.B., Fontana C.S. \& Driemeier D. 2012. Aspergillosis in green-winged saltators (Saltator similis) participants in bird singing competitions. Acta Scient. Vet. 40(4):1089.

Spanamberg A., Ferreiro L., Machado G., Fraga C.F. \& Araujo R. 2016. Identification and characterization of Aspergillus fumigatus isolates from broilers. Pesq. Vet. Bras. 36(7):591-594. <http://dx.doi.org/10.1590/ S0100-736X2016000700005>

Spanamberg A., Machado G., Casagrande R.A., Sales G.M., Fraga C.F., Corbellini L.G., Driemeier D. \& Ferreiro L. 2013. Aspergillus fumigatus from normal and condemned carcasses with airsacculitis in commercial poultry. Pesq. Vet. Bras. 33(9):1071-1075. <http://dx.doi.org/10.1590/S0100736X2013000900004>

Walsh T.J., Anaissie E.J., Denning D.W., Herbrecht R., Kontoyiannis D.P., Marr K.A., Morrison V.A., Segal B.H., Steinbach W.J., Stevens D.A., Van Burik J.A., Wingard J.R. \& Patterson T.F. 2008. Treatment of aspergillosis: clinical practice guidelines of the Infectious Diseases Society of America. Clin. Infect. Dis. 46(3):327-360. <http://dx.doi.org/10.1086/525258><PMid:18177225>

Ziołkowska G., Tokarzewski S. \& Nowakiewicz A. 2014. Drug resistance of Aspergillus fumigatus strains isolated from flocks of domestic geese in Poland. Poult. Sci. 93(5):1106-1112. <http://dx.doi.org/10.3382/ps.201303702><PMid:24795302> 